\title{
Nurmirehun sokeripitoisuuden vaihtelu hevosten ruokintaa ajatellen
}

\author{
Milla Välisalo ${ }^{1)}$, Seija Jaakkola ${ }^{1)}$, Eeva Saarisalo ${ }^{2)}$, Terttu Heikkilä ${ }^{3)}$ ja Mervi Seppänen ${ }^{1)}$ \\ ${ }^{1)}$ Helsingin yliopisto, Maataloustieteiden laitos, 00014 Helsingin yliopisto, etunimi.sukunimi \\ @helsinki.fi \\ ${ }^{2)}$ Maa-ja metsätalousministeriö, elintarvike- ja terveysosasto, PL 30, 00023 Valtioneuvosto, etuni- \\ mi.sukunimi@mmm.fi \\ ${ }^{3)}$ MTT, Kotieläintuotannon tutkimus, 31600 Jokioinen, etunimi.sukunimi@mtt.fi
}

\section{Tiivistelmä}

Hevosalan merkitys maataloudelle on kasvanut viime vuosina ja hevosille tarkoitettujen nurmirehujen viljelyala on lisääntynyt, kun hevosten lukumäärä on Suomessa noussut nykyiseen noin 70 000:een. Hevosen elimistö on sopeutunut käyttämään erityisesti karkearehujen energiaa ja ruokinnan tulisikin rakentua laadukkaiden nurmirehujen ympärille. Nurmirehuissa energia on pääasiassa liukoisina sokereina ja soluseinäkuituina. Ravinnostaan hevonen saa ylläpitoon ja työhön tarvitsemaansa energiaa myös tärkkelyksestä. Nurmien liukoiset sokerit koostuvat mono- ja disakkarideista sekä pidempiketjuisista varastohiilihydraateista. Lauhkean vyöhykkeen nurmikasveissa varastosokerit ovat pääasiassa fruktoosiyksiköistä koostuvia fruktaaneja. Nurmirehujen sokerit ja erityisesti fruktaanit voivat kuitenkin aiheuttaa hevosille myös terveydellisiä ongelmia, joiden syitä voidaan löytää ruokinnan ja käytön epätasapainosta sekä monista tekijöistä liittyen nurmien fysiologiaan ja kehityksen aikaisiin kasvuolosuhteisiin. Nurmirehun raaka-aineen laatu määrittelee sekä laitumena käytettävän tuoreen että varastoitavan rehun laadun. Sokereiden määrä kasvaa tehokkaan yhteyttämisen seurauksena ja noudattaa päivärytmiä, jolloin iltapäivällä sokeripitoisuus on suurempi.

Tämän tutkimuksen tavoitteena oli selvittää kuinka paljon nurmirehun kehitysaste sekä eri fraktioiden (lehdet, korret ja kukinnot) osuus vaikuttaa nurmirehun kokonaissokeripitoisuuteen. Lisäksi selvitettiin nurmirehun sokeripitoisuudessa esiintyvää vuorokausivaihtelua Suomen olosuhteissa sekä kevät- ja syyssatojen sokeripitoisuuksia. Tutkimus toteutettiin peltokokeena Jokioisilla timoteinurminata seoskasvustosta. Näytteenotto suoritettiin neljänä eri ajankohtana, jotka kuvastivat eri korjuuvaiheita tai satoja. Näytteet kerättiin aamulla ja iltapäivällä ja lajiteltiin Simon ja Parkin (1981) mukaan kehitysasteittain viiteen luokkaan sekä fraktioitiin. Näytteistä analysoitiin liukoisten sokereiden määrä.

Tutkimuksen tulosten perusteella kevätsadossa korsiin kertyi merkitsevästi suurempia sokeripitoisuuksia (133 - $191 \mathrm{~g} / \mathrm{kg} \mathrm{ka),} \mathrm{kuin} \mathrm{lehtiin}(81$ - $94 \mathrm{~g} / \mathrm{kg} \mathrm{ka})$. Kun kevätsadon niittoa myöhästytettiin, kertyi $70 \%$ sadon sisältämistä sokereista kukkivista aitokorrellisista versoista, joiden sokeripitoisuus oli suuri (191 g/kg ka). Toisessa ja kolmannessa sadossa sen sijaan aitokorsia ei esiintynyt ja etenkin viimeisessä sadossa syyskuulla lehtien sokeripitoisuus lisääntyi voimakkaasti (201 g/kg ka). Myös toisen sadon valevarsien sokeripitoisuus oli hyvin suuri $(272 \mathrm{~g} / \mathrm{kg} \mathrm{ka})$, mutta niiden osuus rehusadossa oli alle $10 \%$. Monissa aiemmissa tutkimuksissa havaittua sokeripitoisuuden vuorokausivaihtelua ei tämän tutkimusten tulosten perusteella havaittu. Tämä selittyy oletettavasti etenkin keväällä päivän pituudesta ja yön lyhyydestä, joka vähentää sokereiden kulutusta hengitykseen yön aikana. Hevosen vuorokauden aikana saama sokerikertymä, sen syödessä tässä tutkimuksessa käytettyjä rehuja $10 \mathrm{~kg}$ ka, ei näillä nurmirehujen sokeripitoisuuksilla kohoa haitallisen korkeaksi. Arvio perustuu kirjallisuudessa esitettyihin tutkimuksiin, joissa hevoselle on aiheutunut kaviokuumeelle altistavia oireita, kun sille on annettu vuorokauden aikana muun ruokinnan lisänä puhdasta inuliinityyppistä fruktaania. Fruktaanien osuus nurmirehun liukoisista sokereista vaihtelee, mutta se on noin 30-40 \% kaikista sokereista. Erityisesti syyssadossa fruktaanien osuus voi olla huomattavan suuri.

Avainsanat: nurmirehut, hevonen, vesiliukoiset sokerit, korjuuajankohta, vuorokausivaihtelu. 


\section{Johdanto}

Nurmirehut sisältävät hiilihydraatteja noin 3/4 kuivapainostaan (Lillkvist 2002). Hiilihydraatit ovat liukoisina sokereina, tärkkelyksenä sekä soluseinäkuituina (Pollock ja Cairns 1991). Suolistosta imeytyvät hiilihydraattien hajotustuotteet muodostavat hevoselle karkearehujen tärkeimmän energianlähteen ja laadukkaiden nurmirehujen tulisi olla ruokinnan pohjana. Suositusten mukaan hevosille tarkoitettujen nurmirehujen liukoisten sokereiden pitoisuuden tulisi olla välillä 50-150 g/kg ka (Artturiverkkopalvelu 2009). Liukoiset sokerit koostuvat mono- ja disakkarideista sekä pidempiketjuisista varastohiilihydraateista, jotka lauhkean vyöhykkeen nurmikasveissa ovat pääasiassa fruktoosiyksiköistä koostuvia fruktaaneja (Pollock ja Cairns 1991). Fruktaanit ja ruoansulatuksen entsyymien kapasiteetin ylittävät sokerien määrät vaikuttavat hevosilla monien terveydellisten ongelmien, kuten esimerkiksi kaviokuumeen ja metabolisen oireyhtymän syntymiseen (van Eps ja Pollit 2006) ja siksi niiden määrä rehussa kiinnostaa hevosten kasvattajia. Sokereita kertyy nurmiin tehokkaan yhteyttämisen kautta, kun ylimääräinen sokeri varastoidaan väliaikaisesti lehtiin tai kuljetetaan kasvin tyviosassa sijaitseviin sokerivarastoihin. Lauhkean vyöhykkeen nurmikasvit varastoivat pääasiassa fruktaaneja (Cairns ym. 2000). Sokereiden ja fruktaanien kertymiseen vaikuttavat monet tekijät, kuten kasvilaji, kehitysaste sekä ympäristötekijöistä mm. lämpötila, päivänpituus sekä vedensaanti (Chatterton ym. 1989, Solhaug 1991). Tässä tutkimuksessa selvitettiin miten nurmikasvuston kehitysaste, sadonkorjuukerta tai korjuun ajoittaminen vaikuttavat rehuksi korjattavan nurmen sokereiden määrään.

\section{Aineisto ja menetelmät}

Kesällä 2007 kerättiin Jokioisilla kasvustonäytteitä MTT Jokioisten Kartanoiden peltolohkolta L5, jossa oli kolmannen vuoden timotei-nurminata seoskasvusto (Borealin Tuukka-timotei, Ilmarinurminata). Siemenseoksessa timotein osuus oli $54 \%$ ja nurminadan $46 \%$. Näytteet otettiin kolmelta etukäteen määritetyltä koeruudulta, jotka toimivat kokeen kerranteina. Koeruudun koko oli noin 25 $\mathrm{m}^{2}$. Tavoitteena oli ottaa näytteet ensimmäisestä ja toisesta sadosta kasvuston aikaisessa ja myöhäisessä kehitysvaiheessa. Toisen sadon myöhäisen korjuun tilalle otettiin kuitenkin näytteet kolmannesta sadosta syyskuun lopussa lohkolta L7 (toisen vuoden kasvusto, Tuukka-timotei, Anttinurminata, sama seossuhde kuin L5 lohkolla). Molemmat lohkot lannoitettiin Suomensalpietarilla (NK-Ca-Mg-S-B-Se-26-1-3-1-3-0,02-0,001) ensimmäiselle sadolle $370 \mathrm{~kg} / \mathrm{ha}$ ja toiselle $300 \mathrm{~kg} / \mathrm{ha}$. Kolmatta satoa ei lannoitettu. Niittopäivät olivat 13.6. (ensimmäinen sato, aikainen), 26.6. (ensimmäinen sato, myöhäinen), 9.8. (toinen sato) ja 20.9. (kolmas sato). Kasvustonäytteet $\left(0,25 \mathrm{~m}^{2}\right)$ otettiin jokaisesta koeruudusta leikkaamalla maan pinnasta. Näytteiden kasviyksilöt luokiteltiin viiteen kasvuasteluokkaan seuraavasti:1) korren pituuskasvu ei vielä alkanut eli vegetatiivisia versoja (11-19), 2) korren pituuskasvu alkanut, solmuja ei vielä näkyvissä (20-29), 3) varren pidentyminen, solmuja näkyvissä (31-39), 4) tupen turpoaminen (45), 5) tähkän/röyhyn esilletulo (50-58) (Simon ja Park 1981). Kaikkien luokkien kasviyksilöt fraktioitiin lehtiin, korsiin (+ valevarsi) ja kukintoon. Fraktioiden tuorepaino punnittiin ja ne kuivattiin $65^{\circ} \mathrm{C}$ :ssa kaksi vuorokautta. Näytteistä määritettiin vesiliukoiset hiilihydraatit (pelkistävät sokerit) Helsingin yliopistossa (Somogyi 1945). Samanaikaisesti ja samoilta lohkoilta tehdyn säilöntäkokeen raaka-aineesta määritettiin kemiallinen koostumus ja in vitro sellulaasisulavuus MTT Laboratorioissa.

Kasvuston sokeripitoisuuden päivittäistä ja vuorokauden aikaista muutosta seurattiin ottamalla näytteet jokaiselta koeruudulta kunkin niittokerran yhteydessä kolmena päivänä $(-1,0,+1$ pv niittopäivästä) aamulla klo 8 ja iltapäivällä klo 17 niittäen maan pinnasta. Näytteille tehtiin edellä mainittu kehitysasteluokitus. Fraktiointi lehtiin, korsiin ja kukintoihin tehtiin tuorepainon mukaan suurimmasta luokasta. Näytteitä kuivattiin kylmäkuivurissa kaksi vuorokautta. MTT Laboratorioissa määritettiin vesiliukoisten hiilihydraattien pitoisuus (Somogyi 1945) kaikkien päivien näytteistä. Aineiston tilastollinen analysointi tehtiin SPSS-ohjelmistolla (SPSS Inc., USA, versio 17.0). 


\section{Tulokset ja tulosten tarkastelu}

Taulukossa 1 on esitetty koelohkojen kasvustojen kemialliset koostumukset ja sulavuudet niittopäivinä. Sadon 2 kasvusto poikkesi selvästi muista suuremman raakavalkuaispitoisuuden ja pienemmän sokeripitoisuuden vuoksi.

Ensimmäisen sadon niitoissa vesiliukoisia sokereita kertyi rehusatoon erityisesti korsifraktiosta (Kuva 1a ja 1b). Aikaisessa niitossa, jonka D-arvo oli 70,9 \%, sokereita kertyi erityisesti korsifraktiosta, jossa ei vielä esiintynyt kukintoja (Kuva 1a). Niittoa myöhästytettäessä D-arvo laski 67,6 prosenttiin ja sokereita kertyi erityisen runsaasti kukintoja muodostavien kasvien korsifraktiosta (Kuva 1b).

Edellä mainittujen korsifraktioden sokeripitoisuus lisääntyi sadonkorjuuta myöhästytettäessä $133 \rightarrow 190 \mathrm{~g} / \mathrm{kg}$ ka (Taulukko 2). Toisessa ja kolmannessa niitossa korsifraktion osuus oli pieni, ja suurin osa nurmirehun sokereista kertyi kehitysasteeltaan nuorien kasvien lehtifraktiosta (Kuva 1c ja 1d). Yhteenlaskettu rikkakasvien ja kuolleen kasvimateriaalin osuus lisääntyi merkittäväksi. Kevään aikaisessa ja myöhäisessä niitossa niiden osuus kokonaissadosta oli 6-8 \%, kun toisessa niitossa osuus oli $37 \%$ ja kolmannessa niitossa $32 \%$. Lehtien sokeripitoisuus oli erityisen suuri kolmannessa niitossa, $201 \mathrm{~g} / \mathrm{kg}$ ka, jolloin kasvit olivat jo valmistautuneet talvehtimaan. Rikkojen ja kuolleen kasvimateriaalin sokeripitoisuus oli kolmannessa niitossa noin $60 \mathrm{~g} / \mathrm{kg}$ ka. Koko rehumassan sokeripitoisuus jäi pienemmäksi kolmannessa niitossa ollen $165 \mathrm{~g} / \mathrm{kg}$ ka.
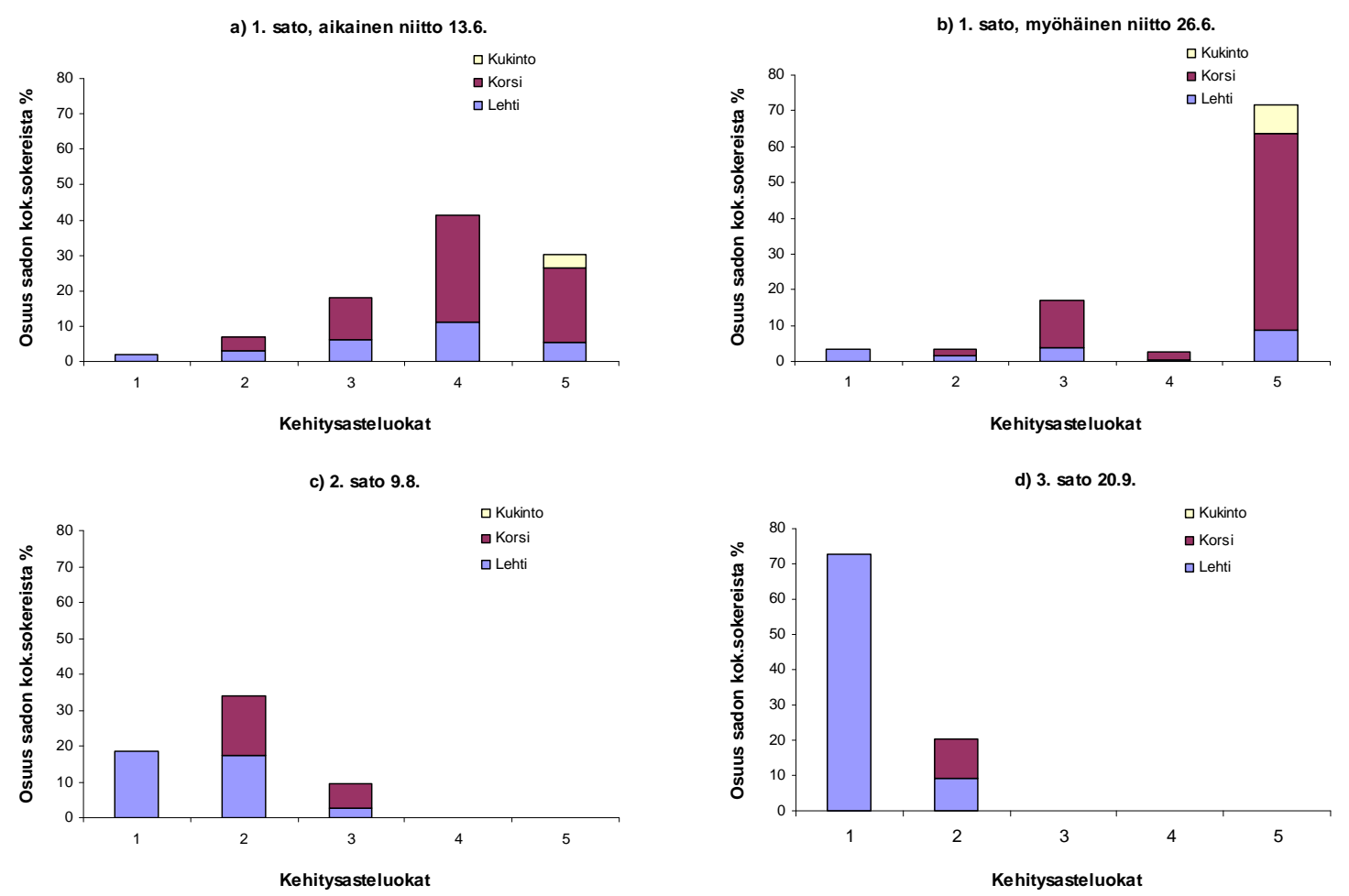

Kuva 1. Eri satofraktioiden sisältämien sokereiden osuus (\%) koko sadon vesiliukoisten sokereiden määrästä a) 1. sato, aikainen niitto, b) 1. sato, myöhäinen niitto, c) 2. sato ja d) 3. sato. Satofraktioiden sokeripitoisuus on mitattu kehitysasteluokittain (1-5), ja pylvään korkeus kuvaa kehitysasteluokan osuutta sadon sokereiden määrästä. Sokeripitoisuudessa ei ole huomioitu rikkakasvien ja kuolleen kasvimateriaalin sokeripitoisuuksia. 
Taulukko 1. Koelohkojen kasvuston kemiallinen koostumus ja in vitro -sulavuus niittopäivinä.

\begin{tabular}{|c|c|c|c|c|}
\hline \multirow{2}{*}{$\begin{array}{l}\text { Sato } \\
\text { Kehitysaste }\end{array}$} & \multicolumn{2}{|l|}{ Sato1 } & \multirow[t]{2}{*}{ Sato 2} & \multirow[t]{2}{*}{ Sato 3} \\
\hline & Aikainen & Myöhäinen & & \\
\hline Niittopäivä & 13.6 .2007 & 26.6 .2007 & 9.8 .2007 & 20.9 .2007 \\
\hline Kuiva-aine, $\mathrm{g} / \mathrm{kg}$ & 226 & 250 & 229 & 205 \\
\hline Kuiva-aineessa, g/kg & & & & \\
\hline Raakavalkuainen & 154 & 144 & 183 & 143 \\
\hline $\mathrm{NDF}^{1)}$ & 550 & 569 & 542 & 533 \\
\hline Sokeri & 148 & 150 & 99 & 165 \\
\hline $\mathrm{D}-\operatorname{arvo}^{2)}, \%$ & 70,9 & 67,6 & 68,2 & 70,6 \\
\hline
\end{tabular}

2) D-arvo = sulavaa orgaanista ainetta kuiva-aineessa, in vitro -sulavuus sellulaasimenetelmällä

Taulukko 2. Koelohkojen kasvustojen lehti-, korsi- ja kukintofraktioiden vesiliukoisten sokereiden pitoisuus (g/kg ka) sekä eri fraktioiden osuudet koko rehumassasta.

\begin{tabular}{|c|c|c|c|c|c|c|c|c|}
\hline \multirow[t]{2}{*}{ Sato } & \multirow[t]{2}{*}{ Päivä } & \multicolumn{3}{|c|}{ Vesiliukoiset sokerit } & \multicolumn{4}{|c|}{ Fraktion osuus kuiva-aineesta } \\
\hline & & Lehti & Korsi & Kukinto & Lehti & Korsi & Kukinto & Rikat/kulo \\
\hline 1. sato aikainen & 13.6 . & 94,2 & $133,0 *$ & 95,0 & 0,35 & 0,53 & 0,05 & 0,08 \\
\hline 1. sato myöhäinen & 26.6 . & 81,1 & $190,9 *$ & 110,5 & 0,28 & 0,54 & 0,12 & 0,06 \\
\hline 2. sato & 9.8 . & 64,1 & 83,4 & 0,0 & 0,44 & 0,19 & 0,00 & 0,37 \\
\hline 3. sato & 20.9 & 201,0 & 271,8 & 0,0 & 0,60 & 0,07 & 0,00 & 0,32 \\
\hline
\end{tabular}

*) $\mathrm{p}<0,05$

Tulokset osoittavat kuinka kevätsadossa korsifraktion sokeripitoisuus voi myöhäisessä niitossa nousta erittäin suureksi, kuten myös myöhään syksyllä lehtifraktiossa. Ensimmäisen sadon korsifraktion sokeripitoisuus lisääntyi erityisesti myöhäisen niiton aikana, jolloin kukinnot olivat jo pitkällä. Nurmikasvin vanhentuessa korren osuus lisääntyy nopeasti lehtiin verrattuna ja niihin kertyy suuria pitoisuuksia liukoisia sokereita (Pearson ja Ison 1997). Kolmannen sadon myöhään syksyllä kerättyjen näytteiden suuren sokeripitoisuuden taustalla on lämpötilojen laskemisen aiheuttama karaistumisen alkaminen. Karaistumisen ensimmäinen vaihe, jolloin kasvi kerää varastohiilihydraatteja, alkaa jo huomattavasti nollan yläpuolella olevissa lämpötiloissa (Fagerstedt ym. 2008).

Vuorokaudenajan vaikutusta nurmirehun sokeripitoisuuteen tutkittiin keräämällä näytteitä aamulla klo 8 ja myöhemmin iltapäivällä klo 17. Sokeripitoisuus vaihteli tutkittujen vuorokaudenaikojen välillä melko vähän (Taulukko 3.). Lehtifraktiossa keskimääräinen sokeripitoisuus oli johdonmukaisesti iltapäivällä suurempi kuin aamulla. Sen sijaan korressa ja kukinnoissa vastaavaa eroa ei esiintynyt. Koska lehtifraktion osuus koko sadosta oli 15-20 \% (Kuva 1a ja 1b), ei vaikutus koko sadon sokeripitoisuuteen ollut merkittävä. Kansainvälisissä tutkimuksissa nurmirehun sokeripitoisuuden vuorokausivaihtelut ovat olleet merkittäviä, joka on johtanut suosituksiin niiton ajoittamisessa (Shewmaker ym. 2006). Päivällä tehokas yhteyttäminen johtaa sokeripitoisuuden lisääntymiseen lehdissä, kun lehtien lyhytaikaiset sokerivarastot täyttyvät. Yön aikana näitä varastosokereita käytetään hengittämiseen, mikä havaitaan alentuneena sokeripitoisuutena aamulla. On mahdollista, että kevään ja kesän pitkä päivänpituus ja yön lyhyys Suomessa johtavat siihen, ettei nurmirehujen sokeripitoisuudessa esiinny merkittävää vuorokausivaihtelua. 
Taulukko 3. Vesiliukoisten sokereiden pitoisuus kasvifraktioissa klo 8 ja 17 eri niittopäivinä (g/kg ka). Näytteet edustavat yleisintä kehityasteluokkaa (Simon ja Park 1981). Arvot ovat kolmen päivän keskiarvoja (keskihajonta) (sato 1, $\mathrm{n}=7$, sadot 2 ja $3, \mathrm{n}=9$ ).

\begin{tabular}{|c|c|c|c|c|c|}
\hline & \multirow[b]{2}{*}{ Kello } & \multicolumn{2}{|l|}{ Sato1 } & \multirow[t]{2}{*}{ Sato 2} & \multirow[t]{2}{*}{ Sato 3} \\
\hline & & Aikainen & Myöhäinen & & \\
\hline Kehitysasteluokka & & 4 & 5 & 3 & 1 \\
\hline \multirow[t]{2}{*}{ Lehdet } & 8 & $110(12,6)$ & $110(6,4)$ & $84(11,7)$ & 225 \\
\hline & 17 & $128(15,7)$ & $118(13,9)$ & $99(14,8)$ & $\begin{array}{c}247 \\
(11,7)\end{array}$ \\
\hline \multirow[t]{2}{*}{ Korret } & 8 & $189(11,7)$ & $221(15,3)$ & $119(18,0)$ & - \\
\hline & 17 & $189(17,3)$ & $227(18,2)$ & $127(23,3)$ & - \\
\hline \multirow[t]{2}{*}{ Kukinnot } & 8 & - & $122(8,7)$ & - & - \\
\hline & 17 & - & $123(9,8)$ & - & - \\
\hline
\end{tabular}

\section{Johtopäätökset}

Tämän tutkimuksen perusteella hevosten nurmirehujen tuotannossa lehti- ja korsifraktioiden suhde kevätsadossa voi antaa viitteitä rehun sokeripitoisuudesta. Yhden vuoden kokeiden perusteella ei voida tehdä yleistyksiä, mutta ainakin kevätsadon korsifraktioihin kertyvät sokerit sekä myöhäisen syksyn kasvien talveentumisesta johtuva sokereiden kertyminen kasvustoon voi olettaa olevan Suomen olosuhteissa jokavuotista. Pitkästä päivästä johtuen vuorokausivaihtelut liukoisten sokereiden pitoisuuksissa näyttäisivät olevan hyvin pieniä. Suomessa vuorokauden ajankohtaa tärkeämpi tekijä niitossa on rehun hygieenisen laadun ja kuivatusprosessin optimointi. Esimerkiksi kostean ja/tai kylmän yön jälkeen kannattaa odottaa kasvuston kuivumista. Ruokinnan kannalta nurmien sokerit lisäävät rehujen maittavuutta ja tarjoavat energiaa, jolloin lisärehujen määrää ei tarvitse kasvattaa kohtuuttoman suureksi. Hevonen pystyy hyödyntämään suurimman osan nurmien sokereista energiakseen ja ruokinnassa olisi hyvä verrata hevosen energiantarpeen ja kulutuksen suhdetta, jolloin löydetään hevoselle sopiva nurmirehu. Arvioitaessa hevosen vuorokauden aikana saamaa sokerikertymää sen syödessä tässä tutkimuksessa käytettyjä rehuja $10 \mathrm{~kg}$ ka, ei sokerimäärä näillä nurmirehujen sokeripitoisuuksilla kohoa haitallisen korkeaksi. Arvio perustuu kirjallisuudessa esitettyihin tuloksiin, joissa hevoselle on aiheutunut kaviokuumeelle altistavia oireita, kuten ripulia ja paksusuolen sisällön pH:n laskua, kun sille on annettu vuorokauden aikana muun ruokinnan lisänä $3 \mathrm{~g} /$ elopainokilo $(1,5 \mathrm{~kg} / 500 \mathrm{~kg}: \mathrm{n}$ painoinen hevonen) puhdasta inuliinityyppistä fruktaania (Crawford ym. 2007). Fruktaanien osuus nurmirehun liukoisista sokereista vaihtelee, mutta se on noin 30-40 \% kaikista sokereista (Pollock ja Cairns 1991). Erityisesti syyssadossa fruktaanien osuus voi olla huomattavan suuri.

\section{Kirjallisuus}

Artturi-verkkopalvelu 2009. https://portal.mtt.fi/portal/page/portal/Artturi/Rehuanalyysi/ Rehuanalyysin_tulkinta_hevoset. Viitattu 25.11.2009.

Cairns, A. J., Pollock, C. J., Gallagher, J. A. \& Harrison, J. 2000. Fructans: Synthesis and Regulation. Photosynthesis: Physiology and Metabolism: 301-320.

Chatterton, N. J., Harrison, P. A., Bennet, J. H. \& Asay, K. H. 1989. Carbohydrate Partitioning in 185 Accessions of Gramineae Grown Under Warm and Cool Temperatures. Journal of Plant Physiology 134: 169-179.

Crawford, C., Sepulveda, M. F., Elliot, J., Harris, P. A. \& Bailey, S. R. 2007. Dietary

fructans carbohydrate increases amine production in the equine large intestine:Implications for pastureassociated laminitis. Journal of Animal Science 85: 2949-2958.

van Eps, A. W. \& Pollit C. C. 2006. Equine laminitis induced with oligofructose. Equine Veterinary Journal 38(3): 203-208. 
Fagerstedt, K., Linden, L., Santanen, A., \& Väinölä, A. 2008. Kasvioppi, siemenestä satoon. 1. painos. Helsinki: Edita Publishing Oy.

Lillkvist, A. 2002. Ruokinnalla tuloksiin 3. 2. painos. Pietarsaari: Forsbergin kirjapaino oy. 308 s. Pavis, N., Chatterton, N. J., Harrison, P. A., Baumgartner, S., Praznik, W., Boucaud, J. \& Prud'homme, M. P. 2001. Structure of fructans in roots and leaf tissues of Lolium perenne. New Phytologist 150: 83-95. Pearson, C. J. \& Ison, R. L. 1997. Agronomy of grassland systems. Cambridge: University Press. $236 \mathrm{p}$.

Pollock, C. J. \& Cairns, A. J. 1991. Fructan metabolism in grasses and cereals. Annual Review of Plant Physilogy Plant Molecular Biology 42: 77-101.

Shewmaker, G. E., Mayland, H. F., Roberts, C. A., Harrison, P. A., Chatterton, N. J. \& Sleper, D. A. 2006. Daily carbohydrate accumulation in eight tall fescue cultivars. Grass and Forage Science 61: 413-421.

Simon, U. \& Park, B.H. 1981. A descriptive scheme for stages of development in perennial forage grasses. Teoksessa: Smith, J.A.\& Hays, V.W. (eds.), Proceedings of the XIV International Grassland Congress at Lexington, Kentucky, USA, June 15-24, 1981, pp. 416- 418.

Solhaug, K. A. 1991. Effects of photoperiod and temperature on sugars and fructans in leaf blades, leaf sheaths and stems, and roots in relation to growth of Poa pratensis. Physiologia Plantarum 82: 171-178.

Somogyi, M. 1945. A new reagent for the determination of sugars. Journal of Biological Chemistry 160: 61-68. 